Аблямитова С. III., аспирант кафедры уголовно-процессуального права имени Н. В. Радутной Российского государственного университета правосудия

\title{
О ПРИМИРИТЕЛЬНЫХ ПРОЦЕДУРАХ В УГОЛОВНО-ПРОЦЕССУАЛЬНОМ ЗАКОНОДАТЕЛЬСТВЕ ЗАРУБЕЖНЫХ СТРАН
}

\begin{abstract}
Аннотация. Статья посвящена исследованию примирительных процедур в уголовном процессе в отдельных зарубежных странах. Отражено процессуальное регулирование таких процедур. Определен порядок применения примирительных процедур в соответствии с уголовно-процессуальным законодательством отдельных государств. Выявлен оптимальный вариант процесса примирения для Российской Федерации.
\end{abstract}

Ключевые слова: уголовный процесс, примирительные процедуры, трансакция, медиация, примирение сторон.

Постановка проблемы. В современном мире разработаны и приведены в действие различные процедуры решения уголовно-правовых конфликтов, которые включают в себя элементы примирения.

Следует учитывать опыт зарубежных стран, где широко используют альтернативные и компромиссные меры при борьбе с преступностью и разнообразные процедуры примирения.

В американском уголовном процессе существует институт соглашения между обвиняемым и потерпевшим. В континентальном праве выделяют другие методы разрешения конфликтов, которые возникают в связи с совершением преступления, такие как трансакция, медиация и ряд других. В частности, трансакция является характерной для нидерландско-бельгийской системы уголовного права и процесса, а медиация применяется в праве целого ряда западноевропейских государств (например, во Франции, Германии, Великобритании, Австрии, Португалии, Канаде, США и других странах).

Такой посреднический подход разрешения конфликта рассматривает преступление как межличностное противоречие, которое заинтересованные лица решают самостоятельно благодаря непрямому содействию третей стороны. Основным предметом обсуждения служит выполнение компенсационных обязанностей [11, с. 21].

Цель статьи - исследование примирительных процедур в уголовном процессе в отдельных зарубежных странах.

Изложение основного материала исследования. Рассмотрим процедуры примирения в отдельных государствах.

Франция. В любой момент расследования уголовное дело прекращается в случае установления одного из оснований, исключающих производство по делу. В соответствии со ст. 6 УПК Франции уголовное дело не может быть возбуждено, а возбужденное подлежит прекращению: в связи со смертью подозреваемого (обвиняемого), за истечением сроков давности, вследствие акта амнистии, вследствие отмены уголовного закона и в случае, если имеется вступивший в законную силу приговор либо постановление или определение суда по тому же обвинению или неотмененное постановление следственного судьи либо обвинительной камеры о прекращении дела по тому же обвинению. Уголовное дело также прекращается за примирением потерпевшего с обвиняемым в случаях, указанных в законе [1, с. 147].

Так, альтернативу уголовному преследованию французский законодатель предусмотрел в ст. 41-1 УПК Франции, согласно которой прокурор, прежде чем принимать решение, вправе начать с согласия сторон процедуру медиации между лицом, подлежащим уголовному преследованию, и потерпевшим. Данная статья подлежит применению по любому уголовному делу [2, с. 101].

Л.В. Головко в своей книге ссылается на автора D. Mondon: «Прокурор более не может рассматриваться только как лицо, отвечающее в силу закона за приведение в движение уголовного преследования. В нем также надо видеть центральный элемент системы согласительных процедур» [13].

Нидерланды. Основной формой примирительных процедур в Нидерландах является трансакция. Сущность ее заключается в том, что правомочные органы (прокуратура и полиция) отказываются от уголовного преследования лица, если оно оплатило в казну установленную в каждом конкретном случае денежную сумму [2, с. 121-155].

Транзакция - это форма отказа от уголовного преследования, когда совершившее уголовно-наказуемое деяние лицо добровольно платит в государственную казну определенную денежную сумму либо выполняет одно или более иное финансовое условие, поставленное прокурором, с тем, чтобы избежать последующего уголовного преследования и публичного разбирательства [3, с. 104-105].

Так, согласно ст. 74 Уголовного кодекса Голландии (выдержка) (также есть 74a, 74 b), перед судебным заседанием прокурор может назначить одно или несколько условий для предотвращения уголовного преследования за уголовные преступления, за исключением тех, за которые закон предписывает наказание в виде тюремного заключения более шести лет, и за проступки.

Соблюдая эти условия, право на судебное преследование прекратится. Возможны следующие условия:

а) выплата государству денежной суммы, которая должна быть определена не менее 3 евро и не больше максимальной суммы штрафа, который может быть наложен за преступление;

b) отказ от права на объекты, которые изъяты и которые подлежат конфискации или изъятию из обращения;

с) отказ от предметов, подлежащих конфискации или выплата государству их оцененной стоимости;

d) выплата суммы денег или передача изъятого имущества, 
чтобы лишить обвиняемого полностью или частично прибыли за незаконную выгоду;

е) полная или частичная компенсация за ущерб, причиненный преступлением;

f) выполнение неоплачиваемой работы или подвержение учебному проекту на срок не более ста двадцати часов [8].

Перечень данных условий является исчерпывающим. Наиболее часто используется выплата в государственную казну соответствующей денежной суммы [2, с. 126]. Размер такой суммы устанавливает прокурор. Если обвиняемый откажется выполнять указанные условия, он будет подвергнут традиционному рассмотрению уголовного дела.

Швейцария. Альтернативой открытию предварительного следствия является медиация.

В Швейцарии история медиации уходит корнями в глубокое прошлое. Не будет преувеличением утверждение, что ее первые ростки появились ещё в Средние века и нашли свое отражение в знаменитом институте «обещания хранить мир». Данная правовая конструкция заключалась в следующем.

Согласно ст. 316 УПК Швейцарии, входящую в главу 3 «Примирительные процедуры»:

1. Если предметом производства являются преступные деяния, преследуемые только по жалобе, прокуратура вправе вызвать заявителя и обвиняемого с целью добиться их примирения. Если заявитель не является, жалоба по делам частного обвинения считается отозванной.

2. Если освобождение от наказания в связи с возмещением принимается во внимание в соответствии со ст. 53 УК, то прокуратура вызывает потерпевшего и обвиняемого на слушания с целью добиться возмещения.

3. Если примирение достигается, то данный факт должен быть отражен в протоколе и подписан участниками. Прокуратура после этого прекращает производство по делу.

4. Если обвиняемый не является на слушания, предусмотренные абз. 1 или 2, или примирение не достигнуто, прокуратура незамедлительно принимает предварительное следствие к своему производству. Она вправе обязать заявителя, когда это обоснованно, в течение 10 суток предоставить обеспечение издержек и возмещения [9, с. 807-808].

Первый вариант примирения: по делам о преступлениях, преследуемых только по жалобе. Данная процедура факультативна, и ее применение зависит от усмотрения прокуратуры. Вместе с тем если заявитель не является, то жалоба по делам частного обвинения считается отозванной (ч. 1 ст. 316). Тем самым государство проверяет серьезность намерений данного лица и размер причиненного ему вреда: если он малозначителен, то, возможно, заявитель не захочет тратить своего времени на участие в переговорных процедурах.

Вторым видом является медиация по делам, прекращение которых возможно в соответствии со ст. 53 УК («Возмещение»). Она устанавливает, что если лицо, совершившее преступление, возместило вред или предприняло все разумные усилия к тому, чтобы загладить совершенное противоправное деяние, то уполномоченный орган отказывается от уголовного преследования, передачи дела в суд или наказания, когда имеются предпосылки для условного осуждения, а также публичные интересы и интересы потерпевшего к уголовному преследованию незначительны. Анализ ст. 53 УК показывает, что перечень деяний, за совершение которых возможно условное осуждение, достаточно узкий, следовательно, медиация может применяться далеко не по всем категориям дел.

Если в ходе дознания соответствующие участники не смогли примириться, то медиация может продолжиться и после открытия предварительного следствия по тем же процессуальным правилам.

Таким образом, медиация возможна только по узкому кругу уголовных дел и в качестве субъекта, который организует примирение, выступает только прокуратура [9, с. 377-378].

Германия. Согласно § 46а УК ФРГ примирение с потерпевшим является основанием отказа суда от назначения наказания, если за совершение деяния предусмотрено лишение свободы на срок до одного года или денежный штраф до 360 дневных ставок и лицо загладило причиненный потерпевшему вред $[12$, c. 74].

УПК ФРГ предусматривает возможность прекращения производства дела при исполнении обязательств и указаний (§ 153a).

Согласно данной статье необходимо различать прекращение процесса на стадии дознания и после предъявления обвинения.

Прекращение процесса прокуратурой. На стадии дознания процесс можно прекратить при наличии следующих обстоятельств:

1) Речь должна идти об уголовно наказуемом проступке.

2) Степень вины не должна препятствовать этому. Вместе с тем закон исходит из наличия определенной степени вины. Поскольку уголовный процесс ещё не был проведен, то достаточно наличия достаточного подозрения в совершении преступления (= вероятности осуждения). В результате отрицательной формулировки, что степень вины не должна препятствовать этому, следует, что также подпадают под действие и преступления средней тяжести.

3) Возложенные на обвиняемого обязанности и указания должны быть предназначены для устранения общественного интереса по осуществлению уголовного преследования.

В частности, прокуратура может возлагать на обвиняемого (названные обязанности):

- загладить вред, причиненный деянием (§ 153в, № 1);

- внести денежную сумму в пользу общественно полезного учреждения или в государственную казну (№ 2);

- выполнить другую общественно полезную работу (№ 3);

- обязанность содержания потерпевшего путем выплаты определенной денежной суммы (№ 4);

- всерьез заботиться о получении потерпевшим компенсации (№ 5);

- принимать участие в конструктивном семинаре при пробном получении водительского удостоверения (§ 2b закона о правилах уличного движения) или в рамках оценочной системы (§ 4 VIII закона о правилах уличного движения) (№ 6).

Перечень, указанный в $§ 153 \mathrm{a}$, не является исчерпывающим. Прокуратура и суд могут возложить на обвиняемого выполнение иных обязанностей и указаний (неназванных обязанностей). Однако такое право прокуратуры и суда не является безграничным. Прокурор не всегда может возложить на обвиняемого выполнение такой обязанности, как мойка машины или стрижка газона. Обязанности и указания должны находиться в связи с совершенным уголовно наказуемым деянием [10, c. 199]. 
4) Для решения в некоторых случаях необходимо согласие суда (например, при преступлениях, связанных с нарушениями правил дорожного движения).

5) Для прекращения процесса необходимо получить согласие обвиняемого.

6) Сначала процесс только приостанавливается. Решение о приостановке не подлежит обжалованию. Если обвиняемый не выполнит возложенные на него обязанности или указания, то процесс может возобновиться. Но если обвиняемый выполнил возложенные на него обязательства, то прокуратура должна окончательно прекратить в отношении него процесс. Это является окончательным обстоятельством, препятствующим дальнейшему ведению процесса [10, с. 200].

После предъявления обвинения возможно прекращение процесса судом. Должны быть в наличии те же предпосылки, что и для прекращения прокуратурой.

Так, суд может с согласия прокуратуры и обвиняемого временно прекратить производство до окончания судебного разбирательства, в рамках которого могут быть в последний раз установлены фактические обстоятельства, и одновременно возложить на обвиняемого обязанности или дать указания, описанные ранее [4, с. 228].

Испания. В Испании медиация применяется преимущественно в области ювенальной юстиции и является способом перевоспитания несовершеннолетних. В этой сфере работа ведется как организациями Автономных Сообществ Испании, так и командами, которые работают с прокуратурой по делам несовершеннолетних, и рядом других организаций. Согласно данным статистики в 15-20 \% всех преступлений, совершенных несовершеннолетними, применяются процедуры медитации. В них принимают участие преступники и их жертвы [7].

Польша. Законом от 30 марта 1965 г. в Польше были созданы внесудебные институты для принятия мер к примирению конфликтующих сторон по делам частного обвинения - так называемые общественные примирительные комиссии. Законом от 2 декабря 1960 г. была введена обязательная дополнительная стадия процесса - примирительное производство, которое должно предшествовать главному судебному разбирательству [5, с. 207].

С 1995 г. в Польше проводятся программы медиации по делам несовершеннолетних по инициативе Пенитенциарной ассоциации Патронат.

В 1998 г. были приняты Уголовный и Уголовно-процессуальный кодексы. Они дали возможность прекращать дела за примирением по расширенному составу дел [6, с. 162].

Выводы. На основании вышеизложенного автор считает, что правовая конструкция примирения сторон в Российской Федерации напоминает европейский вариант медиации французскую медиацию (как поиск решения конфликта, возникшего между его участниками). Общепризнанным является то, что институт медиации является альтернативным способом урегулирования уголовно-правовых конфликтов, в основе которого лежит посредничество в примирении сторон конфликта. Главной целью решения конфликта является не наказание виновного, а устранение причиненного вреда путем достижения консенсуса между его сторонами и сохранение спокойствия в обществе.

Но в отечественном варианте отсутствует посредник по примирению сторон, другими словами, лицо, совершившее преступление, должно самостоятельно, а не по предложению государственных органов принять решение о примирении с потерпевшим и возместить ему причиненный ущерб. В процессе примирения отсутствует полный набор сторон (лицо, совершившее преступление; жертва; посредник). Предполагается, что их наличие способствовало бы наибольшей эффективности процесса примирения.

\section{Литература:}

1. Амбасса Леон Шанталь Предварительное следствие в уголовном процессе России и Франции: Сравнительно-правовое исследование: дисс. ... канд. юрид. наук: спец. 12.00.09. Москва, 1999. 161 с.

2. Головко Л.В. Альтернативы уголовному преследованию в современном праве. СПб.: Издательство «Юридический центр Пресс», $2002.544 \mathrm{c}$.

3. Головко Л.В. Альтернативы уголовному преследованию как форма процессуальной дифференциации: Современные тенденции развития: дисс. ... докт. юрид. наук: спец. 12.00.09. Москва, 2003. $463 \mathrm{c}$.

4. Головненков П.В., Спица Н.А., Хелльманн У. Уголовно-процессуальный кодекс Федеративной Республики Германия: науч.-практ. комментарий и перевод текста закона. М.: МГЮА им. О.Е. Кутафина, 2012. $404 \mathrm{c}$.

5. Защита прав потерпевшего в уголовном процессе. М., 1993. C. 207.

6. Минулин Р.М. Прекращение уголовных дел в связи с примирением сторон: монография. Тюмень: Тюменский юридический институт МВД РФ, 2006. 198 с.

7. Обзор законодательства Испании о медиации. URL: $\mathrm{http}: / /$ mediators.ru/rus/about_mediation/foreign_law/spain/text1 (дата обращения: 07.12.2018).

8. Текст Уголовного кодекса Голландии. URL: https://wetten.overheid. nl/BWBR0001854/2018-10-16 (дата обращения: 10.12.2018).

9. Трефилов А.А. Уголовный процесс зарубежных стран. М.: ООО «НИПКЦ Восход-А», 2016. 1020 c.

10. Бойльке В. Уголовно-процессуальное право ФРГ: учеб. для студентов юрид. фак. / Пер. с нем. Я.М. Плошкиной; М-во образования и науки Рос. Федерации, Краснояр. гос. ун-т. 6-е изд., с доп. и изм. Красноярск: Краснояр. гос. ун-т, 2004 (ООО ИПЦ КаСС). 351 с.

11. Усc А.В. Примирение вместо наказания (как течение в правоприменительной практике). Правоведение. 1990. № 6. С. 20-26.

12. Юрченко И.А. Уголовное право зарубежных стран: учебное пособие для магистрантов. Москва: «Проспект», 2014. 107 с.

13. Mondon D. Justice improsée, justice négociée: les limites d'une opposition, l'exemple du parquet. Droit et Société. 1995. № 30/31. 
Аблямітова С. Ш. Про примирювальні процедури в кримінальному процесуальному законодавстві зарубіжних країн

Анотація. Стаття присвячена дослідженню примирювальних процедур в кримінальному процесі окремих зарубіжних країн. Відображено процесуальне регулювання таких процедур. Визначено порядок застосування примирювальних процедур відповідно до кримінального процесуального законодавства окремих держав. Виявлено, який варіант процесу примирення є оптимальним для Російської Федерації.

Ключові слова: кримінальний процес, примирювальні процедури, трансакція, медіація, примирення сторін.
Abliamitova S. About the reconciliation procedures of the criminal procedural law in foreign countries

Summary. The article is devoted to the study of reconciliation procedures in the criminal process in certain foreign countries. Procedural regulation of such procedures is reflected. The procedure for the application of conciliation procedures in accordance with the criminal procedural law of certain states is specified. The optimal version of the reconciliation process for the Russian Federation is revealed.

Key words: criminal procedure, reconciliation procedures, transaction, mediation, reconciliation of the parties. 